\title{
1年を経たMITのオープンコースウエア
}

\author{
宮川 繁 ${ }^{2}$ 著 \\ 高木和子 ${ }^{2}:$ 訳
}

\begin{abstract}
著者抄録 : マサチューセッツ工科大学は 2001 年にそのすべての授業資料をWeb上のオープンコース ウエアに無料で公開すると発表し, 2003年にはそこで提供されるコース数が500を超えるまでになっ た。MITがオンライン教育をどのように作り出し, 提供できるか, 財政面での実行可能性, 持続可 能性, プログラムの目標をもとに検討し, 次にe-ラーニングの展望, 市場調査とビジネスモデルの作 成, などを研究するなど, オープンコースウエア（OCW）の実現までの過程を述べた。そしてOCW の資金調達, それへの教員の参加, オンライン授業教材の知的所有権の問題, OCWの利用者, OCW のコースについて紹介する。

キーワード : MIT, オープンコースウエア, Web, 遠隔教育, 遠隔教育教材, 著作権, オンライン授

業, 資金, ビジネスモデル
\end{abstract}

\section{MIT's open course ware after one year}

\section{written by MIYAGAWA Shigeru ${ }^{1}$ \\ translated by TAKAGI Kazuko²}

\begin{abstract}
Author Abstract: Massachusetts Institute of Technology (MIT) announced in 2001 that it would make available over the web for free the teaching materials of all the courses taught at MIT. In 2003 the number of courses from virtually exceeded 500. First the author describes the process leading to the Open Course Ware (OCW); studies on how MIT created and provided online education financially viable and sustainable way, and in terms of the program objectives, and studies on e-learning prospect, marketing research, business models, so on. Then he introduces OCW funding, the faculty involvement, copyright of the teaching materials on the Web, OCW users, OCW courses.
\end{abstract}

Key words: MIT, open course ware, Web, distance education, distance education teaching material, copyright, online education, fund, business model

\section{1.はじめに}

2001 年 4 月, マサチューセッツ工科大学 (Massachusetts Institute of Technology, MIT) は，ほ ぼすべてのコースの授業資料をWeb上で無料公開 すると発表した。オープンコースウエア (Open

1マサチューセッツ工科大学 E-mail: miyagawa@mit.edu 2科学技術振興機構「情報管理」編集事務局気付（干1028666 東京都千代田区四番町5-3)

${ }^{1}$ Foreign Languages and Literatures Section, Massachusetts Institute of Technology (14N-305, MIT, Cambridge, M 02139 USA)

${ }^{2}$ c/o Japan Science and Technology Agency (5-3, Yonban-cho, Chiyoda-ku, Tokyo, 102-8666)
Course Ware, OCW) (http://ocw.mit.edu)と呼ばれるこ の大規模な Web ベースのプロジェクトは，コン ピュータサイエンスから生物学, 物理学, 数学, 経 済学, 言語学, 歴史, 外国語, その他多くの広範 囲な専門分野にわたってMIT教員のコース資料を 公開するようデザインされている。なぜMITがこ れを行っているのだろうか? それは教育におけ る世界のリーダーであるというMITの中心的使命 の直截的な反映ともいえよう。MITは研究ゆえに 国際的名声を得てきた伝統を持つが,今ここにOCW をもって大学教育の模範となることを意図する。 OCW上に公開されたコース数が500というマイル ストーンに達した2003年9月に, MITの学長Charles M. Vestは, 次のように語った。 
「MITは, 2001年にオープンコースウエアが発表 された時の約束に従って仕事をしてきた。世界の あらゆる地域の教育者や学習者がOCWはすでに教 育や学習にインパクトをもたらしていると言って いるのをうれしく思う。私たちはOCWを, 教育の 力を民主化し, さらに変容させるうえでの新しい ドアを開くものとみなしている。コース資料をオー プン共有するという考えが多くの機関に広まり, 学習の質を高め, 結局は, 世界的に生活の質を高 めるグローバルな知識網を作りだすことを期待す る」。

OCWへのばく大な数のアクセスを言うなら,2003 年夏になる前までの時点で, OCW上にアップロー ドされた50ほどのコースは, 210を超す国家・領土・ 都市国家から合計約 1,200 万件のヒットがあった。 米国のある教育者は電子メールで次のようなメッ セージを書いている。

「立ち止まらないで。いかなるハードルがあろう ともこのプロジェクトを推し進めてください。私 はコースを詳細に検討した。そして, サイトがス ムーズに機能すること, 私が予想していた以上に 多くの情報が得られることがわかった。秋が来る のが待ちきれない思いだ。おめでとう！」。

OCWのWebサイトはここ数か月の間に, そのテ クノロジー, コンテンツ, 利用者体験, およびデ ザインが認められ，数多くの賞や評価を得た。

・ 2003 年インターネット・ビジネス・ソリューショ ン(Internet Business Solution of the Year)。2003年, 10月15日,何千という候補の中からOCW と Sapient 社がマイクロソフトより受賞

・Info World 100。2003年, 11月10日, 最前線テクノ ロジーが評価され, Info World Magazineより受賞 ・2003年ベスト教育Webサイト (Best Educational Web Site)。2003年10月21日, Massachusetts Interactive Media Council (MIMC)より受賞

・2003年ベストユーザ体験(Best User Experience)。 2003年10月21日, MIMCより受賞

・京都デジタルアーカイブ賞 (Kyoto Digital Archives Award)。2003年1月30日, MITがWWWを教育に役 立て, 情報の保管に新機軸を取り入れたことが たたえられて受賞

\section{2. オープンコースウエアヘと導く過程}

最終的にOCWにつながったイニシアチブは, MIT のCouncil on Educational Technology (MITCET 教育 技術評議会)でスタートした。MITのプロヴオスト
であるRobert A. Brownが共同議長を務めるMITCET は,「テクノロジーを教育に応用するためのインフ ラストラクチャーとイニシアチブを開発するため に戦略的ガイダンスを提供し, MITの取り組みを 監視する注1」。MITCETは2000年春に生涯教育(LifeLong Learning, LLL)のための新イニシアチブを開始 し, MITコミュニティーのさまざまなメンバー:教 員, 管理者, 大学院生から成るLLLのコアチームを 任命した注2。工学部の副学部長であるDick Yue教授 に率いられて, LLLチームは,「ターゲット市場に 対して, 現在のホットな問題と新規の分野に実際 的な理解をもたらす “オンライン教育” モジュー ルを, MITがどのように作りだし, 提供すること ができるのかを述べた勧告を作成する」ことになっ た。これらの3つの条件を満たすための必要なモ ジュールは注 3 :

・財政面での実行可能性

・持続可能性

・プログラムの目標

当時, インターネットバブルは最高度に達して おり, e-ラーニングは世界中の, 中でも米国の大 学や会社（定評のある団体も, 新しい組織も同じ く）にとって極めて説得力のある流行語であった。 これらの団体はベンチャーの立ち上げを開始して, 市場リーダーシップや資金調達獲得を争っていた。 収益を求めるか否かについては調査を待つことに なっていたが, 時代の高揚に合わせて, コアチー ムは「財政的に実行可能で持続可能」とするため に, 収益創出の戦術を作りだすアイデアから始め た。戦略の財政面とビジネス面を見越して, コン サルティング企業であるBooz, Allen and Hamiltonの メンバーが, 計画のすべての局面を支援するため にコアチームに参加した。コアチームは 2000 年6月 に仕事を開始し, 2 3時間の会議を週に数回もっ た。私はそのチームのメンバーであった。チーム は11月までにエグゼクティブスポンサーに勧告を 出すことになっており, 勧告を出すまでの期間, チームはエグゼクティブスポンサーやステイクホ ルダグループ (利害関係者) に会って, そのつど 進ちょくを報告し，アドバイスを求めた注4。2000

注1) このパラグラフ中の引用は, すべて MITCET の Web サイトhttp://web.mit.edu/cet/ からのものである。

注2) 生涯教育コアチームのメンバーは, 次の Web サイト に記載されている。http://web.mit.edu/cet/

注3) これらの条件のいくつかと「ホットな問題と新規 の分野」のアイデアは, McKinseyとともに行われ たMITCET初期の研究の中で明らかにされた。 
年11月, コアチームは OCWを主要な勧告項目とす る報告書をプロヴォストBrownに提出した。

生涯教育(LLL)チームは, 収入を生み出す戦略か らスタートし，いかにして最後にOCWを勧告した のだろうか? 後になって考れば，すべての断片 がどのようにして統合されたかを理解するのは容 易であるが，LLLチームがアイデアを検討してい る過程では，10月の最後の週ですらこのコアチー ムメンバーにとっては何も明確なものはなかった。 締め切りが迫るにつれて解決策が明らかになって いき，当初はいささか二番手の策と見なされてい た解決策，つまりOCWが完璧な答えとされたので あった。5か月にわたる考察に考察を重ねたすべて のアイデアのなかでも, コンテンツを無料で提供 するというコンセプトは, ぎりぎりまで検討され たことは決してなかった。コアチームが検討を終 えてそれを結論に反映する機会が出るまでは, OCW の選択は時期尚早だっただろう。

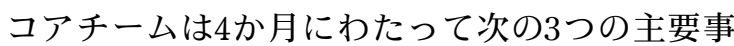
項を検討した。

・e-ラーニングに携わる教育機関と企業の諸団体に 対し, MITが面接する

・市場調査とビジネスモデルを作成する

・MITで実施されている現行のe-ラーニングプロ ジェクトを評価する

・e-ラーニングの展望

外部機関を対象とする面接は, e-ラーニングべ ンチャーおよび, 手広く社内e-ラーニング研修プ ログラムを実施する大企業, そしてe-ラーニング プログラムを実施する高等教育機関に対し行った。 面接は米国を本拠地とする機関，および数社であ るがヨーロッパの参加企業に対して行った。4か月 間で主にテレビ会議を使って約40の面接が行われ た。外部面接は, 多数の重要な課題をかかえるコ アチームを大いに啓発した。すでにさまざまな形 態で多数のe-ラーニング活動が存在していたが,高 等教育の最もダイナミックな分野での立場を打ち

注4) エグゼクティブスポンサーのメンバーは, プロ ヴオストRobert A. Brown, Thomas Magnanti工学部 学部長, Richard Schmalenseeスローン経営大学院 学部長であった。利害関係者グループには同空 会, プロヴオストオフィス, 学部, 図書館, そし てキャンパスのさまざまな教育技術グループの 代表が含まれた(エグゼクティブスポンサーは中 核的運営管理者のグループで, 何が組織的に道理 にかなうかを中核的運営管理の見解からアドバ イスする)。
立てるために, MITが独自のイニシアチブを開始 すべきことは明白であった。問題は「MITは何が できるか?」であった。この問題は研究データが 多くなるに従って,答えるのはますます難しくなっ

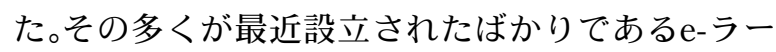
ニング企業は,「ブランド」価值のあるコンテンツ をライセンス契約するために大学と, 時として著 名な学者と直接契約を結んでいた。これはひとつ には2000年末までに株式公開 (Initial Public Offering, IPO)をするために必要な戦略であった。MITが同 様な道を歩むことは不適切であっただろう。MIT は，すでに独自のe-ラーニングに携わっている他 の機関と契約を結ぼうとはしなかったであろう。 またMITは非営利機関であるので, 株式公開をす ることも絶対にできない。手短に言えば,コアチー ムは他のいくつかの高等教育機関がやったように (例えば, コロンビア大学のFathom.com), MITの利 益追求部門に着手することを考慮したが，この戦 略は及ばなかった。

○市場調査とビジネスプラン

生涯教育イニシアチブのためのビジネスプラン を開発するにあたり，コアチームは市場調査のた めにMIT卒業生からデータを集めた。MIT卒業生は 対象利用者のセグメントを代表する。つまり同大 学の卒業生は専門家であることが多いからである。 電子メールで5,000名にアンケートを送り，10\%の 回答率を得た。アンケートは基本的なプロフィー ルに加えて, e-ラーニング登録の目的/意図, 料金, 利用可能な時間, テクノロジー, 双方向性の望ま しいレベルといった, 実行可能なe-ラーニングプ ログラムの詳述に対する回答を求めた。コアチー ムは多くの財政上のシナリオを使ってデータを分 析し，一連のビジネスモデルを作成した。市場調 查から多くの驚くべき知見が得られた。人々は忙 しすぎて長時間にわたる り遂げられないという, 驚くにたらない結果も得 られた。コアチームを驚かせたのは, 何人かの回 答者が利用できるのであればモジュールを基本と したコースが最良の選択であると示唆したことで あった。モジュールはそれぞれが20～30分を要す るが，これではあまりにも短すぎてどんな主題も 深く扱えない。このことや, 望ましい双方向性の レベル（当然のことながら若い回答者はより多く の双方向性を望んだ), 支払う意思のある料金（支 払う料金の額と支払い者の間には直接的相関関係 があり，一企業が払う場合はその相関関係がより 高い）といったその他の特性は, 生産コストと管 
理コストに関連して概念的なデータベース上と， 最大限の収益をあげるために研究された種々の組 み合わせの中に詳細に描かれた。

この過程で重要な点は, コアチームが総じてビ ジネスモデルを厳密にかつ学問的に開発するうえ での情報を得たことで, 情報をもとにビジネス決 定ができるようになったことである。卒業生から 得た回答に, 生産コストや管理コストのような他 のタイプのデータが加えられ，一連のシナリオを 分析し, その結果多様なビジネスモデルが得られ た。最も妥当と思われるモデルのひとつは, プロ グラムが 5 年内に財政的に自立することを可能にす るものであった。それは毎日報告される「ニュー エコノミー」のニュースや, コアチームが調査し ていたイニシアチブと同タイプのものが生み出し ているばく大な富と,鋭い対極をなすものであった。

\section{○教員の中心価值 : 優秀な教育}

外部面接と, 市場調査とビジネスシナリオは, 当初の収入を生み出す戦略という初期のアイデア に疑いを投げかけた。MITはユニークな戦略を定 義するためにできることは明白でなく, 財政面で 利益があるのかも問題であった。しかし, 収入を 生み出す戦略の代替策をコアチームが真剣に, 結 局は検討できるよう導いたのは第3番目の調査で あった。コアチームは, 現在MITキャンパスで行 われているe-ラーニングプロジェクトに関する電 子メール質問に回答した約 60 人の教員を面接した。 これらのプロジェクトはすべて教員が教えている MITコースの一部であった。e-ラーニングプロジェ クトはテキストベースのWebサイトから, 講義の オンラインビデオまで多岐にわたっており，いず れも学習上の質問を伴うものであった。

この面接からコアチームの思考の中で決定的と なった $2 つ の$ 教訓が得られた。オンライン資料の 作成になぜ教員が従事するのかという疑問に対す る答えは, 例外なく, 教員は自分の教えるコース の質を向上させたいと望むからであるというもの であった。2番目に, わずかな例外を除いて, 教員 はその仕事に金銭上の補償を得ていなかった。こ れらの面接から，たとえ他の活動のための時間を 犠牲にしてでも, 教師は自分たちが教えるコース 授業の質を絶えず向上させようとする教師として の責任の一環として, 授業づくりにかかわるとい うことが主たる価值であるとみていることがわかっ た。

\section{○OCWの起源}

コアチームは 2000 年10月初めの会合で，すべて
の調査結果を検討した。多くの質問が出されたが, その中で最も力のこもった質問は,「どのようなタ イプのe-ラーニングプロジェクトが, 教えるとい う教員の責務の中心価值を最も良く反映するか」 であった。オンラインで無料公開するMITのコー ス資料，というアイデアが多くのメンバーから自 発的に現れたのはその時である。事実, おそらく, 教員が自分たちの授業資料が世界中の学習者に利 益をもたらすというアイデアに価值を見い出して いたことは，もっともであると思われた。

OCWはMITでの教育体験とイコールにはなりえ ない,つまりMITの教育体験はMITに在学して, 教 授たちと交流し, 学生仲間とともに暮らし学ぶこ とによってのみ経験できることを心に留めること が重要であった。OCWのアイデアは, 収入を作り 出す体制を作る必要がなく, したがって他の調査 の中で確認された諸問題－その最も顕著なものが 十分な収入を作り出すことであったが，これらを 避けられるという付加的な利点があった。MITの オンラインコース教材は, インターネット経済の 時代のビジョン, すなわち, MITは財政的な利益 よりも教育を重んじ, e-ラーニングは, 教育への 熱意を支援できるものである, という強力なメッ セージを送ることにもなろう。しかしイニシアチ ブを作り出すことは無料でということにはならな い。コアチームの最後の仕事は, 制作コストと管 理コストを含めたOCWのビジネスモデルを作るこ とであった。10年間にわたりMITの全2,000コース からオンライン教材を創り出すために8,500万ドル という数字が見積もられた。最終的にコアチーム はOCWを勧告した。驚くほど簡単なアイデアであ るが, その意義はe-ラーニングの展望とそのビジ ネスの現実を理解するために行われた幅広い調査 なしには明らかにならなかったであろう。

OCWのコンセプトは11月にプロヴオストとその 他のエグゼクティブスポンサーのメンバーに勧告 され，そのアイデアと報告書全文は熱狂的に受け 入れられた。その後, MIT学長 Charles Vestに報告 された。学長も等しく熱意をもってそれを受け入 れた。MITのCouncil on Educational Technology (MITCET 教育技術評議会)のメンバーから成る チームは, MITのすべての学科とプログラムのメ ンバーにそれぞれ説明した。2001年10月に大学教 授会でOCWの討論を重ねた。教員から出された最 も重大な疑問は, 実施, コスト, そしてMITの教育 を無料で与えてしまうことへの恐れに関するもの であり，そのすべてにMITCETのメンバーによっ 
て直接説明を加えた。それに対する支持は強く, 4 月4日のプレスリリースでのOCW発表への道を開 いた。数日のうちにOCWの発表は世界中の新聞や 他のメディアに配信された。

\section{OCWの資金調達}

コアチーム最後の仕事のひとつはOCWの予算を 用意することであった。コアチームはMITの2,000 を超えるコースすべてをOCWに載せるための費用 として 8,500 万ドルという数字を提示した。OCWを 始められるように,2002年7月, MITはアンドリュー。 $\mathrm{W}$ ・メロン財団とウィリアム\&フローラ・ヒュー レット財団からそれぞれ同額の寄付を受けた。総 額で1,100万ドルの助成金であった。それに加えて， MITも 2 年間に自己資金で100万ドルをOCWに充て ることにした。

\section{OCWと教員}

OCWのキーは, 教員の参加がまったくの自由意 志であることである。コース教材をOCWに提供す るかどうかを決めるのは教授一人一人の自由に任 せられている。もしそうではなくMITがOCWへの 参加を義務化していたならば，それは教員の自主 性に敬意を払うというMITの基本的風土に反して いたであろう。参加を奨励するには，OCWの基盤 を構築するだけでなく, 参加したいとする教員を サポートできるような体制を作り上げなければな らかった。この組織は2002年春にOCWの事務局長 に任命されたAnne Marguliesによって率いられてい る。Ms. MarguliesのリーダーシップによりOCWの 組織が創られた。組織はいわゆる「ハイブリッド」 型である。すなわち, Ms. Marguliesの直接的な上 司はプロヴオストであり，彼に対し報告するので あるが, Ms. Marguliesが組織を代表するものの, 大 学内の各学科や他部門にもOCWの代表を配してい るからである。後者の配置は, 教員は中央集権的 な組織から与えられるサービスの質に懐疑的であ るとの調査結果から生まれた。教員は自分達の利 益を配慮する者が自分たちの部門の中にいること を知れば安心する。この各学部に配置されたOCW 代表は, 教員の参加をできるだけ能率的に行える ようなサポートを提供する。2003年秋に行われた 調査で, OCWへの体験に関し, 現在OCWに参加し ている教員にアンケートをとった。回答者の $74 \%$ が，OCWに公開する教材準備に10時間ないしそれ
以下を費やしたと答えている。注目に值するのは， 全回答者の $42 \%$ は 5 時間か, それ以下であったと答 えたことである。これは，OCWの支援システムが 計画どおりに機能していることを示す最初の具体 的な内容であった。

オンライン授業教材をWeb上で得られるように することは知的所有権の問題につながる。誰が授 業教材を所有するのか? 個々の教員か, それと もMITか？ MITはほとんどの大学と同じく,大学 の学部（ファカルティ）の著作になっている教科 書の所有権をその著者に譲渡する。ほとんどの教 授は，これと同じ方針が通常の講義ノートや関連 教材にも適用されるものと承知してきている。こ れら教材の電子版を誰が所有するかという問題点 はMIT の事務局が出した声明で解決されている。 つまり, 教員が自分のコース用に作成した教材は それがWeb互換フォーマットに変換されたとして も依然としてその教員が所有するというものであ る。

知的所有権方針の2番目の領域は, 著作権で保護 されている第三者のコンテンツの利用である。通 常の授業では, 教員は何よりも見解のバランスを 確保するために他の学者の資料を取り入れる。こ れを教室内ですることは問題ではなく, 米国の著 作権ではフェアユース（公正利用）条項で可能と なっている。しかしながら, 著作権が存在する第 三者の資料を含めた授業教材すべてをWeb上で提 供するとなると問題が別である。OCWはそのスタッ フに著作権専門家チームを配して,この問題が提 起する多くの問題を解決する。一例を挙げると, 私は，「文化を視覚化する」と呼ばれるコースhttp:/ /ocw.mit.edu（歴史のページに行き，それから 「Visualizing Culture」に行く) を歴史学のProfessor John W. Dowerとともに教えている。このコースは, 歴史的事件から生み出された視覚イメージを通し て，人はどのようにして歴史を理解できるのかを 見る。最初のユニットとして, 私たちは1853/1854 年のMatthew Perry総督の日本到着を取り上げ, 200 以上のイメージ (木版刷り, 古い写真, リトグラ フ，地図など）を米国と日本にある博物館，個人 コレクション, 貴重書から集めた。これらのイメー ジをOCWに載せる許可を受けるために，私たちは 2003年夏の大半をOCWの法律チームとともに取り 組んで過ごした。幸運にも私たちが選び出したコ レクションの所有者は寛大で, OCWイニシアチブ に好意的であった。しかし, 深刻な難問に直面す るコースもある。例えば，フィルムを扱うコース 
がそうである。OCWに最も容易に載せられる資料 は，教員自身が作った資料である。OCW上のコー スをいちべつすると, シラバスからPowerPointで 作られた詳細な講義ノート, 宿題, そして少数の 例では前学期に実際に実施された期末試験まで, 教員が作った資料が驚くほど豊かで多様であるこ とがわかる。

教員はOCWコース教材をどのように利用するの

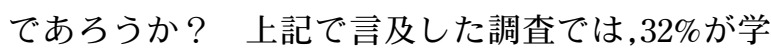
生にアドバイスするため, 研究するため, そして 教える準備のためにOCWを利用すると報告した。 「OCWは, 私が他の科目の学習を向上させるに役 立った/役立つであろう」と, 回答者の $68 \%$ が賛成 あるいは強く賛成していることは心強い。これは, 教材利用に関心のあるいずれの人々の益になるよ う教材を誰にでも利用できるようにするという， OCWの使命をサポートするということなのである。

\section{OCWの利用者}

現在OCWを利用している人たちは満足している のであろうか？ 2003年11月6日から19日にかけて， 無作為抽出したOCW利用者21,500名に対し簡単な アンケート調査を実施し, そのうち 1,220 名から回 答を得た。回答者の $92 \%$ はコース教材の質に満足 であった。回答者の $95 \%$ は, 今後もOCWのWebサイ トにアクセスすると答えた。99\%の回答者が,OCW は「極めてプラスの」または「どちらかというと プラスの」インパクトを世界中の教育に及ぼすと 答え，83\%は「極めてプラスの」を選んだ。これら の結果は電子メール経由でOCWに八ってくる内容 とも共鳴するものである。つまり，OCWはコース 教材への容易なアクセスを提供するので, MIT以 外の教員利用者はそれを自分の授業に自由に組み 入れられる，そして，それが高等教育自体を向上 させることになるということである。

できるだけ幅広い参加を促すために，OCWは言 語と文化の障壁を乗り越える方向に動いている。 2003年1月にOCWは, ラテンアメリカ, スペイン, ポルトガルの 650 大学のコンソーシアムである Universia.netと,OCWの25の主題をスペイン語とポ ルトガル語に翻訳し, Universia.netのWebポータル サイトhttp://www.universia.netで提供するために正 式な協定を結んだ。Universia.netはそのうちの最初 の10程度の翻訳主題をすでに開発している。世界 の他の多数地域の代表者と話し合いがなされてお
り, 近い将来ますます多くのOCWコースが外国語 で見られるようになり，世界中に置かれるサーバ からアクセスできるようになろう。

\section{OCWのコース}

最終の章では, OCWに参加しているすべての学 科とその他の大学部門のリストを載せる。最後に 「看板」コースをいくつか, OCW組織の電子メール ニュースレターであるOCW Updatesから直接引用

して紹介する。

○2003年12月現在における大学の部門

1. 電気工学, コンピュータサイエンス

2. 数学

3. スローン大学院（経営）

4. 経済学

5. 物理学

6. 機械工学

7. 脳. 認知科学

8. 航空/宇宙

9. 外国語, 外国文学

10. 建築

11. 歴史

12. 言語学, 哲学

13. 生物学

14. 文学

15. 化学

16. 土木工学, 環境工学

17. 材料科学

18. 都市工学, 都市計画

19. 健康科学, 医療技術

20. 政治学

21. 人類学

22. 海洋工学

23. ライティング・人間学

24. 科学, 技術, 社会

25. メディアアーツ・科学

26. 化学工学

27. 工学システム部

28. 地球大気 - 惑星科学

29. 原子力工学

30. 音楽, 舞台芸術

31. 生体工学部

32. 比較メディア学

33. 女性学 


\section{OCWコースの例（OCW Updatesよ り引用）}

○コース STS.069: Technology in a Dangerous World (危険な世界におけるテクノロジー)

MIT科学, 技術, 社会 (STS)のプログラムの中の 1コース。MITのRosalind Williams教授（プログラム 責任者）が重要な時事の諸問題を, それらから技 術の世界の本質について何が露見するかについて 分析した。コースの出発点は, 技術とテロリズム の関連であり，人間が建てた世界がいかに不安定 状態や危険を助長しうるか，そしてどのように人 類がそれに対応するかについて探求することであ る。コースの中で取り扱われるトピックは，技術 のリスクとその矯正，社会技術システム，惨事の 想像，技術とアイデンティティ，技術と宗教，技 術と教育, 技術と信頼が含まれる。Williams教授は, MITOCWコースのサイトに入門的なエッセイを載 せた。このエッセイは当教材作成に関する背景情 報を与えるもので, サイト訪問者はそのコースを 始めるに先立って一読するよう勧めている。教材 セクションは, 時事問題をSTSの観点から調べる 学生達に対してWilliams教授から送られるクラス討 議への洞察を与える一連の電子メールや, STS学 生に求められる宿題のリスト, そして文献リスト を含んでいる。この文献リストにはManuel Castells の著書End of Millenniumからの論文 “The Rise of the Fourth World”, Anthony Giddensの著書 The Consequences of Modernity, Donald MacKenzieの著書 Knowing Machines: Essays on Technical Changeから のエッセイ “Computer-Related Accidental Death” が 含まれる。9月11日のテロリスト攻撃が起こったす ぐ後の2001年10月1日に行われた「技術, 戦争, テ ロリズム」に関するMITティーチインのビデオも 見ることができる。クリップにはMIT Center for International StudiesのTed Postol教授, STSのDavid Mindell準教授, MIT Center for Environmental Initiatives のDavid Marks所長による講演が含まれて いる。

○コース 11.422: Business Improvement Districts

（ビジネス改善地区）

MIT都市研究および都市計画http://dusp.mit.edu/ no のひとつのコースである。MITのLorlene Hoyt教 授がビジネス改善地区の特質を探り, 講義ノート セクションで紹介される世界各国の多数のケース スタディについても同様のことを行う。このトピッ クをさらに深く研究するための詳細な文献リスト
もある。Lorlene Hoyt教授のシラバスによって, 事 実上清潔で安全な野外の公共空間であると支持者 たちが主張するビジネス改善地区(BIDs)のトピッ クが紹介される。その一方，このように公的基金 を与えられて私的に管理される団体の急増を検討 し, それが都会地域の政治的, 経済的, 社会的, 空 間的な細分化に及ぼす程度を問いかけることが重 要である。宿題のセクションでは, コースのため の4つの宿題を出している。

・ビジネス改善地区の包括的な定義を巧みに作る こと

・短いリサーチペーパーを書くこと

・「ビジネス改善地区, 敵か味方か?」という題の 12 ページのペーパー

・学んだ教訓の統合 : ボストン市への提言

○コース 2.875: Mechanical Assembly and Its Role in Product Development（製品開発におけるメカニ カルアセンブリとその役割)

MIT Center For Technology, Policy, and Industrial Development の上級研究者であるDaniel E. Whitney 教授が, メカニカルアセンブリのデザインと組み 立てへの系統的なアプローチを紹介するが，これ は機械工学, 製造工学, 経営工学部の学士終了者 用コースの学生のみならず, 工業技術専門家の興 味を引くものである。個々の部品のデザインや製 造については数多く書かれるが, どのようにして これらの部品が集まって実際に何かを行うひとつ の製品になるかについての情報は驚くほど少ない。 このコースは次の疑問に取り組む。適格にデザイ ンされたアセンブリとは何か, そういうアセンブ リを見たときどうしてそうと知りえるのか? 学 生の個々の目標とは, アセンブリの問題を分析す る系統的なアプローチを理解すること,アセンブ リが製品開発と製造に影響を与える多くの方法を 評価すること, 技術・システム工学・経済分析を 含む完全なアプローチを了解すること, 自分自身 の1学期間にわたるプロジェクトに系統的なプロセ スを実践することが含まれる。コースのサイト上 では完全なプロジェクトガイドラインが提供され る。Whitney教授の講義ノートは，アセンブリのた めの小デザインの中でのアセンブリ,アセンブリ • システム・デザイン・ソフトウエア，そして離散 事象シミュレーションといったトピックを深く掘 り下げ,さらに767水平安定板 (horizontal stabilizer) のためのデザインにおける事例研究を学生に与え る。 